\title{
Awareness, knowledge and perception of in-vitro fertilization among final-year medical students in South-West Nigeria
}

\begin{abstract}
Background: In-vitro fertilization is a component of Assisted Reproductive Technique.

Objective: To evaluate awareness, knowledge and perception of final year medical students in In-vitro fertilization.

Method: A semi-structured questionnaire was served to 126 participants in September 2015.

Result: Mean $[ \pm \mathrm{SD}]$ age of the 69 males $(27.1,4.2)$ in the study was significantly difference $(\mathrm{t}=3.15$; $\mathrm{P}$ value $=0.001)$ from that of the 57 females $(25.1,2.9)$. In all, approximately $35 \%$ were sexually active 6 months prior to the survey, including $28 \%$ and $3 \%$ with one and with $\geq 4$ heterogenous sexual partners respectively while almost $37 \%$ had never had sex. Three $(5.3 \%)$ females and $2(2.9 \%)$ males had their first heterosexual intercourse at age $\leq 15$. Almost $63 \%$ of them heard of IVF during lectures. About $90 \%$ knew that IVF involves bringing egg and sperm together outside the body and putting fertilized egg back into the womb. While $84 \%$ regarded IVF babies as normal, $72 \%$ thought that it is too expensive, though $70 \%$ would opt for IVF in case of infertility. In all, $82 \%$ agreed that the wife is commonly blamed for infertility.
\end{abstract}

Conclusion: Major source of information on IVF was during medical lectures. Most of the respondents knew of basic IVF procedure. Assisted Reproductive Technology should be stressed more in medical curriculum.

Keywords: medical students, In-vitro fertilization, awareness, perception
Volume 2 Issue I - 2017

\author{
Abayomi Ajayi,' Victor Ajayi,' Oluwafunmilola \\ Biobaku,' Ifeoluwa Oyetunji,' Happiness \\ Aikhuele,' Bamgboye MAfolabi ${ }^{2}$ \\ 'Nordica Fertility Centre, Nigeria \\ ${ }^{2} \mathrm{Health}$, Environment and Development Foundation, Nigeria
}

Correspondence: Bamgboye M Afolabi, Health, Environment and Development Foundation, 34 Montgomery Road, Yaba, Lagos, Nigeria, Tel +234(0) 803-049-0729, +234(0) 808-0081946,Email bmafolabi@gmail.com

Received: November 04, 2016 | Published: January 19, 2017

\section{Introduction}

In-vitro fertilization (IVF) is a complex series of technologically driven procedures used to treat infertility or genetic problems and assist with the conception of a child. ${ }^{1}$ During IVF, mature eggs are collected (retrieved) from a woman's ovaries and fertilized by spermatozoa in the laboratory. ${ }^{1}$ The pioneering work of Patrick Steptoe and Robert Edwards gave birth to "In-vitro fertilization" and Louise Joy Brown, the first test tube baby, was born on the 25 th of July, $1978 .{ }^{2}$ Since then, the science of IVF has taken the world by storm and this technology with its various processes are now been made available in almost every country though the developing countries still lag behind. ${ }^{3}$ In Nigeria, few government and private establishments have successfully adopted and promoted this technological process and it is operational. Still, the populace is not well informed about its presence and availability and trying to do this has been another herculean task. The literacy level of the populace has not helped matters as the country ranks as one of the sub-Saharan African countries with the lowest literacy rates. ${ }^{4}$

Added to this, is the attitude, beliefs and cultural practices of the local populace towards accepting new technologies. Even among the ranks of the enlightened few (including medical personnel), understanding and adopting the procedures and processes of invitro fertilization remains a formidable challenge due to the lack of appropriate information, technical know-how and finance. Medical doctors that should know also seem to have some knowledge gaps and need to be educated themselves and therefore the authors of this article decided to carry out this research among medical students (our doctors of tomorrow) to find out how aware they are of this technology -which can be deployed to solve the problem of infertility- and also understand their perception of IVF.

The problem of infertility is a very significant social and cultural issue especially with the high premium placed on having children in family settings in Nigeria and Africa. Clinically, it seems the burden of infertility is rising with the increasing population and also data collation. The aspiration of our women folk to acquire western education up to tertiary level has sometimes necessitated that they put initiating reproductive cycles on hold till later years. Also, their desire to secure economic stability prior to attempting conception, the fact that female fertility declines with advancing age, and that the reproductive phase in women is relatively short in comparison to their entire life span (while that of males is maintained with only slight decline until old age) has also led to an increase in this burden of infertility. ${ }^{5}$

All this have combined to make the problem of infertility -which is defined as the inability of a couple to achieve conception despite regular unprotected sexual intercourse for a year- remain a big "headache" for couples with the problem. However, assisted reproductive techniques have come to the rescue and with in-vitro Fertilization being its flagship, there is hope that the burden of this problem can be significantly impacted upon.

A lack of awareness about fertility in young people and among 
women seeking fertility treatment may increase the duration of fertility and eventually they may require in-vitro fertilization. Some of the studies carried out in the past have focused on the women seeking fertility treatment and nursing personnel. Studies in South-East Nigeria found that $95.1 \%$ of 122 nurses surveyed ${ }^{6}$ and only $37.6 \%$ of women respondents attending gynecological fertility clinic were aware of in-vitro fertilization.?

Adesiyun \& his colleagues ${ }^{8}$ found that of 176infertile women interviewed in Northern Nigeria, about $76.5 \%$ had heard of assisted reproductive techniques but more than $50 \%$ were not sure if the babies from it were normal or natural.

This study, likely the first to survey medical students about IVF in Nigeria, aims to assess the awareness, knowledge and perception of In-vitro fertilization by final year medical students in South -West Nigeria.

\section{Materials and methods}

\section{Design and data collection}

The study was a descriptive cross-sectional investigation conducted among final year medical students in February 2015. Data was collected at a gathering of final year medical students to mark their valedictory lecture. Questionnaires containing 20 questions some multiple choice and others open ended questions - designed to acquire information on knowledge, attitude and perception of In-Vitro Fertilization (IVF), were administered to interviewees who gathered for their final graduating lecture.

Permission and cooperation were obtained from their teachers to distribute questionnaires for the study. Only students who refused to take part in the study after explaining the importance and addressing their concerns including confidentiality or who improperly or incompletely filled the questionnaires were excluded from the study. A pilot study was initially conducted among laboratory and nursing staff of Nordica Fertility Centre, Lagos ( $\mathrm{n}=15)$.

\section{Setting}

The study was conducted at the College of Medicine of a tertiary Teaching Hospital, in Sagamu, Ogun State in South -West Nigeria, about $70 \mathrm{~km}$ from metropolitan Lagos, the economic capital of the country.

\section{Participants}

One hundred and fifty questionnaires were distributed among the final year medical students of the university. This was based on the average number of students (120) expected in the graduating class of majority of medical schools in Nigeria. Sample size was increased to 150 to cater for non-response. Students who refused participation or returned incomplete or improperly filled questionnaires were excluded from the study.

\section{Research instrument}

A self-administered questionnaire with closed format questions was used. It had two sections. Section A contained questions on sociodemographics and elicited responses on age, religion, gender, marital status, sexual activity among other sociodemographic characteristics. Section B had questions on awareness, knowledge and perception on In Vitro Fertilization.

\section{Data analysis and presentation}

The responses from returned and properly completed questionnaires were collated, entered into an Excel spread sheet in a laptop and coded accordingly. The coded data was cleaned before final analysis using STATA 13 computer software. Chi square analysis was done and odds ratio was calculated where applicable. Level of confidence was set at $\mathrm{P}<0.05$. Results were presented in tables and figures.

\section{Ethical consideration}

The study was approved by the ethical board of Nordica Fertility Centre, Lagos.

\section{Results}

One hundred and twenty-six (females: 57, 45,2\%; males:69, $54.8 \%)$, with overall mean $( \pm$ sd) age of 26.2 (3.8) years, participated in the study. Males were significantly older than females $(\mathrm{t}=3.15$, $\mathrm{P}$-value $=0.001)$. Figure 1 illustrates the age distribution of the medical students which shows unimodal appearance with a peak at 27 for males and 26 for females. Only 12 (7 males and 5 females) of the medical students were married, though there was no significant statistical difference in marital status of females and males $\left(\chi^{2}=0.92\right.$, $\mathrm{P}$-value $=0.34)$ though males were approximately $13 / 4$ more like to be married than females $(\mathrm{OR}=1.79,95 \% \mathrm{CI}: 0.54,5.98)$. In all, $81 \%$ of the students were Christians and only $19 \%$ were Muslims. Although very few $(3.2 \%)$ were already parents, majority $(91.3 \%)$ wish to be a parent (Table 1).

Sexual history of the medical students, which shows that approximately $35 \%$ of them were sexually active 6 months prior to the study, is as illustrated in Table 2. The Table also shows that $79(62.7 \%)$, $35(27.8), 4(3.2 \%), 1(0.8 \%)$ and another $4(3.2 \%)$ had $0,1,2,3$ and 4 or more sexual partners within the past 6 months. Incidentally, those who had 2 or 3 sexual partners in the past 6 months were males and those who had 4 or more sexual partners were females. Majority $(36.5 \%)$ had never had heterogenous sexual intercourse before while $24.6 \%$ had their first sexual intercourse at age over 20 years, $21.4 \%$ at age between 19 and 20 years and only $4 \%$ at age 15 years or less, especially females $(5.3 \%)$. The mean $( \pm \mathrm{sd})$ age at menarche of females was 13.0(1.4)years with $77.2 \%$ of them have regular menstrual activity. All the females had normal cycle interval of 21-35days.

The study probed further into age at first sexual experience for both male and female respondents relevant to the number of sexual partners they had 6 month prior to the study (Table 3) (Table 4). Among males who had 1 sexual partner 6 months prior to the study, $2(16.7 \%)$ had first heterogenous sexual experience at age 15-18years compare to 3 (60.0\%) females who had their sexual experience between age 15-18 years. Of the 4 females who had 4 or more sexual partners in 6 months prior to the survey, $3(75 \%)$ had first heterogenous sexual experience at age less than 15 years and $1(25.0 \%)$ at age between 15 and 18 years.

Sources of information on In-vitro fertilization (IVF) among the respondents was mainly at lectures (62.7\%), magazines/journals/ books (37.3\%) and from Radio and Television (34.9\%) indicating that educational system confers knowledge on IVF on students more than other sources of information (Figure 2).

Eight domains were used to assess the respondents' knowledge and perception of IVF. These domains were

i. How is IVF performed? 

ii. Is it possible for a woman to have a baby after menopause?
vi. Who is commonly blamed for infertility in the society?
iii. Are IVF babies normal?
vii. Do you think test-tube babies are or should be socially accep- table? and
iv. What's your biggest worry about IVF?
v. What option would you choose in case of infertility?
viii. Should Fertility drugs be socially acceptable?

Table I Socio-demographic characteristics of respondents

\begin{tabular}{|c|c|c|c|c|}
\hline Variable & Item & Male & Female & All \\
\hline \multirow{6}{*}{ Age (Years) } & Number (\%) & $69(54.8)$ & $57(45.2)$ & $126(100.0)$ \\
\hline & Mean & 27.1 & 25.1 & 26.2 \\
\hline & $\pm \mathrm{SD}$ & 4.2 & 2.9 & 3.8 \\
\hline & Median & 27 & 25 & 26 \\
\hline & Mode & 27 & 26 & 27 \\
\hline & t-test (P-value) & $3.15(0.001)$ & & - \\
\hline \multirow{4}{*}{ Marital Status } & Single & $64(92.8)$ & $50(87.7)$ & II 4 (90.5) \\
\hline & Married & $5(7.2)$ & $7(12.3)$ & $12(9.5)$ \\
\hline & $\chi^{2}$ (P-value) & $0.92(0.34)$ & & - \\
\hline & OR $(95 \% \mathrm{Cl})$ & $1.79(0.54,5.98)$ & & - \\
\hline \multirow{6}{*}{ Family Position } & Ist (\%) & $21(30.4)$ & $16(28.1)$ & $37(29.4)$ \\
\hline & 2nd (\%) & $14(20.3)$ & $19(33.3)$ & $33(26.2)$ \\
\hline & $3 r d(\%)$ & $18(26.1)$ & $5(8.8)$ & $23(18.3)$ \\
\hline & 4th (\%) & $8(11.6)$ & $9(15.8)$ & $17(13.5)$ \\
\hline & 5 th $(\%)$ & I (I.4) & $7(12.3)$ & $8(6.3)$ \\
\hline & $>5$ th $(\%)$ & $7(10.1)$ & $\mathrm{I}(\mathrm{I} .8)$ & $8(6.3)$ \\
\hline \multirow{3}{*}{ Number of Children in Family } & $<5(\%)$ & $37(53.6)$ & $42(73.7)$ & $79(62.7)$ \\
\hline & $5-9(\%)$ & $27(39.1)$ & I5 (26.3) & $42(33.3)$ \\
\hline & $\geq 10(\%)$ & $5(7.3)$ & $0(0.0)$ & $5(4.0)$ \\
\hline \multirow{2}{*}{ Religion } & Christian (\%) & $53(76.8)$ & $49(86.0)$ & $102(81.0)$ \\
\hline & Islam (\%) & $16(23.2)$ & $8(14.0)$ & $24(19.0)$ \\
\hline \multirow{2}{*}{ Are you already a Parent? } & Yes (\%) & $3(4.3)$ & $\mathrm{I}(\mathrm{I} .8)$ & $4(3.2)$ \\
\hline & No $(\%)$ & $66(95.7)$ & $56(98.2)$ & $122(96.8)$ \\
\hline \multirow{4}{*}{ Wish to be a Parent } & Yes (\%) & $63(91.3)$ & $52(91.2)$ & $115(91.3)$ \\
\hline & No (\%) & $2(2.9)$ & $\mathrm{I}(\mathrm{I} .8)$ & $3(2.4)$ \\
\hline & Don't know (\%) & $\mathrm{I}(\mathrm{I} .5)$ & $3(5.3)$ & $4(3.2)$ \\
\hline & Already a parent (\%) & $3(4.3)$ & $\mathrm{I}(\mathrm{I} .8)$ & $4(3.2)$ \\
\hline
\end{tabular}

Table 2 Sexual history of respondents by gender

\begin{tabular}{|c|c|c|c|c|c|c|c|c|c|}
\hline \multirow{2}{*}{ Sexual Activity } & \multirow{2}{*}{ Item } & \multicolumn{2}{|l|}{ Male } & \multicolumn{2}{|c|}{ Female } & \multirow{2}{*}{$\begin{array}{l}\chi^{2} \\
\text { (P-value) }\end{array}$} & \multirow[t]{2}{*}{ OR (95\% CI) } & \multicolumn{2}{|l|}{ All } \\
\hline & & Freq. & $\%$ & Freq. & $\%$ & & & Freq. & $\%$ \\
\hline \multirow[t]{2}{*}{$\begin{array}{l}\text { Sexually active in past } 6 \\
\text { Months }\end{array}$} & Yes & 25 & 36.2 & 19 & 33.3 & 0.12 & 1.14 & 44 & 34.9 \\
\hline & No & 44 & 63.8 & 38 & 66.7 & -0.73 & $(0.54,2.38)$ & 82 & 65.1 \\
\hline \multirow[t]{2}{*}{$\begin{array}{l}\text { How many Hetero-Sexual } \\
\text { Partners in past } 6 \text { Months }\end{array}$} & 0 & 44 & 63.8 & 38 & 66.7 & 0.12 & 0.88 & 79 & 62.7 \\
\hline & & & & & & -0.73 & $(0.42,1.84)$ & & \\
\hline
\end{tabular}




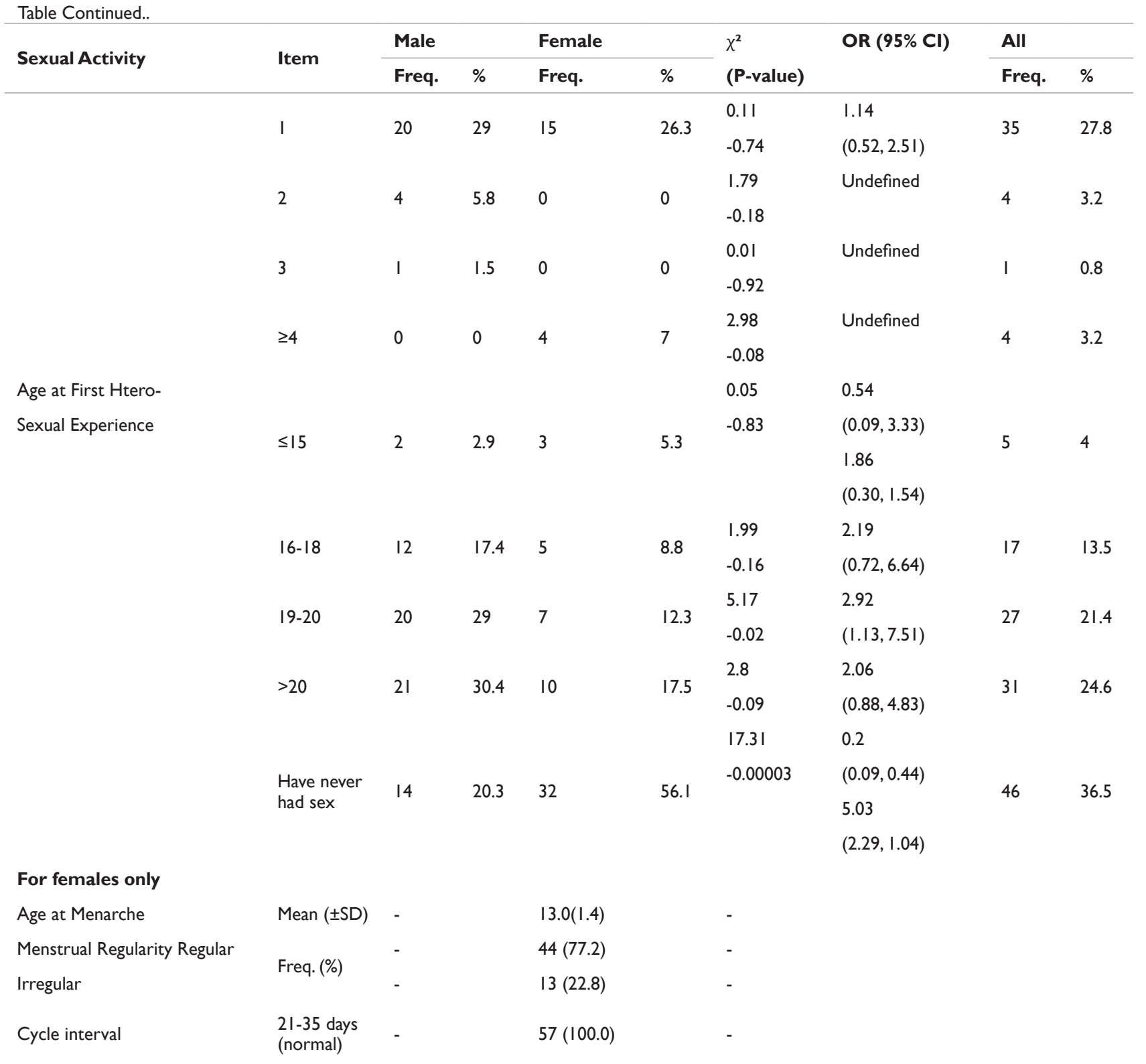

Table 3 Cross-tabulation between age at first heterogeneous sex and number of sexual partners 6 months before the study

\begin{tabular}{|c|c|c|c|c|c|c|c|c|c|c|c|}
\hline \multirow{5}{*}{ Variable } & \multirow{5}{*}{ Item } & \multicolumn{10}{|c|}{ Age at first sexual activity } \\
\hline & & \multicolumn{5}{|l|}{ Male } & \multicolumn{5}{|l|}{ Female } \\
\hline & & $<15$ & $15-18$ & $19-20$ & $<20$ & $\begin{array}{l}\text { Never } \\
\text { had sex }\end{array}$ & $<15$ & $15-18$ & $19-20$ & $>20$ & $\begin{array}{l}\text { Never } \\
\text { had sex }\end{array}$ \\
\hline & & $\begin{array}{l}\text { Freq. } \\
\text { (\%) }\end{array}$ & Freq. & Freq. & Freq. & Freq. & Freq. & $\begin{array}{l}\text { Freq. } \\
\text { (\%) }\end{array}$ & $\begin{array}{l}\text { Freq. } \\
\text { (\%) }\end{array}$ & $\begin{array}{l}\text { Freq. } \\
\text { (\%) }\end{array}$ & Freq. \\
\hline & & & (\%) & (\%) & (\%) & (\%) & (\%) & & & & (\%) \\
\hline \multirow{5}{*}{$\begin{array}{l}\text { Number } \\
\text { of sexual } \\
\text { partners } \\
\text { in past } 6 \\
\text { months }\end{array}$} & 0 & $0(0.0)$ & $8(66.7)$ & $10(50.0)$ & $12(57.1)$ & $14(100.0)$ & $0(0.0)$ & $I(20.0)$ & $2(28.6)$ & $3(33.3)$ & $32(100.0)$ \\
\hline & 1 & $0(0.0)$ & $2(16.7)$ & $9(45.0)$ & $6(28.6)$ & $0(0.0)$ & $0(0.0)$ & $3(60.0)$ & $5(71.4)$ & $7(66.7)$ & $0(0.0)$ \\
\hline & 2 & $0(0.0)$ & I (8.3) & $0(0.0)$ & $3(14.3)$ & $0(0.0)$ & $0(0.0)$ & $0(0.0)$ & $0(0.0)$ & $0(0.0)$ & $0(0.0)$ \\
\hline & 3 & $0(0.0)$ & $0(0.0)$ & I (5.0) & $0(0.0)$ & $0(0.0)$ & $0(0.0)$ & $0(0.0)$ & $0(0.0)$ & $0(0.0)$ & $0(0.0)$ \\
\hline & $\geq 4$ & $2(100.0)$ & I (8.3) & $0(0.0)$ & $0(0.0)$ & $0(0.0)$ & $3(100.0)$ & I (20.0) & $0(0.0)$ & $0(0.0)$ & $0(0.0)$ \\
\hline
\end{tabular}


Table 4 Knowledge and perception of In-vitro fertilization among medical students

\begin{tabular}{|c|c|c|c|c|c|c|c|c|}
\hline \multirow{3}{*}{ Variable } & \multirow{3}{*}{ Response } & \multirow[t]{2}{*}{ All } & \multicolumn{4}{|c|}{ Age (years) } & \multicolumn{2}{|l|}{ Sex } \\
\hline & & & $<20$ & $20-24$ & $25-29$ & $\geq 30$ & Male & Female \\
\hline & & Freq. (\%) & Freq. (\%) & Freq. (\%) & Freq. (\%) & Freq. (\%) & Freq. (\%) & Freq. (\%) \\
\hline \multirow{5}{*}{$\begin{array}{l}\text { How is IVF } \\
\text { performed? }\end{array}$} & $\begin{array}{l}\text { Growing babies in test tube } \\
\text { for } 9 \text { months }\end{array}$ & $8(6.3)$ & $0(0.0)$ & $2(6.5)$ & $5(6.3)$ & I (7.I) & $4(5.8)$ & $4(7.0)$ \\
\hline & $\begin{array}{l}\text { Bringing egg and sperm } \\
\text { together outside the body } \\
\text { and putting fertilized egg } \\
\text { back into the womb }\end{array}$ & II2 (88.9) & $2(100.0)$ & $27(87.1)$ & $70(88.6)$ & $13(92.9)$ & $62(89.9)$ & $50(87.7)$ \\
\hline & $\begin{array}{l}\text { Manufacturing sperm and } \\
\text { egg }\end{array}$ & I (0.8) & $0(0.0)$ & $0(0.0)$ & I (I.3) & $0(0.0)$ & $0(0.0)$ & I (I.8) \\
\hline & Selling of babies & $0(0.0)$ & $0(0.0)$ & $0(0.0)$ & $0(0.0)$ & $0(0.0)$ & $0(0.0)$ & $0(0.0)$ \\
\hline & Don't know & $5(4.0)$ & $0(0.0)$ & $2(6.4)$ & $3(3.8)$ & $0(0.0)$ & $3(4.3)$ & $2(3.5)$ \\
\hline \multirow{3}{*}{$\begin{array}{l}\text { Is it possible } \\
\text { for a woman } \\
\text { to have a } \\
\text { baby after } \\
\text { menopause? }\end{array}$} & Yes & $79(62.7)$ & I (50.0) & $17(54.8)$ & $49(62.0)$ & $12(85.7)$ & $42(60.9)$ & $37(69.9)$ \\
\hline & No & $46(36.5)$ & I (50.0) & $14(45.2)$ & $29(36.7)$ & $2(14.3)$ & $26(37.7)$ & $20(35.1)$ \\
\hline & Don't know & $\mathrm{I}(0.8)$ & $0(0.0)$ & $0(0.0)$ & $\mathrm{I}(\mathrm{I} .3)$ & $0(0.0)$ & $\mathrm{I}(\mathrm{I} .4)$ & $0(0.0)$ \\
\hline \multirow{4}{*}{$\begin{array}{l}\text { Are IVF babies } \\
\text { normal? }\end{array}$} & No & $4(3.2)$ & $0(0.0)$ & I (3.2) & $3(3.8)$ & $0(0.0)$ & I (I.4) & $3(5.3)$ \\
\hline & Yes & $106(84.1)$ & $2(100.0)$ & $25(80.6)$ & $66(83.5)$ & $13(92.9)$ & $59(85.5)$ & $47(82.5)$ \\
\hline & Not sure & $12(9.5)$ & $0(0.0)$ & $3(9.7)$ & $8(10.1)$ & I (7.I) & $6(8.7)$ & $6(10.5)$ \\
\hline & Don't know & $4(3.2)$ & $0(0.0)$ & $2(6.4)$ & $2(2.5)$ & $0(0.0)$ & $3(4.3)$ & I (I.8) \\
\hline \multirow{6}{*}{$\begin{array}{l}\text { Biggest worry } \\
\text { with IVF }\end{array}$} & Don't believe it works & $0(0.0)$ & $0(0.0)$ & $0(0.0)$ & $0(0.0)$ & $0(0.0)$ & $0(0.0)$ & $0(0.0)$ \\
\hline & Not sure babies are normal & $3(2.4)$ & $0(0.0)$ & $3(9.7)$ & $0(0.0)$ & $0(0.0)$ & $2(2.9)$ & I (I.8) \\
\hline & Too expensive & 91 (72.2) & $2(100.0)$ & $19(61.3)$ & $57(72.2)$ & $13(92.9)$ & $5 \mathrm{I}(73.9)$ & $40(70.2)$ \\
\hline & It doesn't work all the time & $21(16.7)$ & $0(0.0)$ & $6(19.4)$ & 14 (I7.7) & I (7.I) & $9(13.0)$ & $12(2 \mid .1)$ \\
\hline & $\begin{array}{l}\text { Religious perspective about } \\
\text { IVF }\end{array}$ & $7(5.6)$ & $0(0.0)$ & I (3.2) & $6(7.6)$ & $0(0.0)$ & $6(8.7)$ & I (I.8) \\
\hline & Others & $4(3.2)$ & $0(0.0)$ & $2(6.4)$ & $2(2.5)$ & $0(0.0)$ & I (I.4) & $3(5.3)$ \\
\hline \multirow{4}{*}{$\begin{array}{l}\text { Option in case } \\
\text { of infertility }\end{array}$} & IVF & $89(70.1)$ & I (50.0) & $21(67.7)$ & $61(77.2)$ & $6(42.9)$ & $5 \mathrm{I}(73.9)$ & $38(66.7)$ \\
\hline & Adoption & $26(20.6)$ & I (50.0) & $8(25.8)$ & II (I3.9) & $6(42.9)$ & $13(18.8)$ & $13(22.8)$ \\
\hline & Abstain from children & $0(0.0)$ & $0(0.0)$ & $0(0.0)$ & $0(0.0)$ & $0(0.0)$ & $0(0.0)$ & $0(0.0)$ \\
\hline & Not sure & II (8.7) & $0(0.0)$ & $2(6.4)$ & $7(8.9)$ & $2(14.3)$ & $5(7.2)$ & $6(10.5)$ \\
\hline \multirow{4}{*}{$\begin{array}{l}\text { Who is } \\
\text { commonly } \\
\text { blamed for } \\
\text { infertility in } \\
\text { the society? }\end{array}$} & Husband & $2(1.6)$ & $0(0.0)$ & $2(6.4)$ & $0(0.0)$ & $0(0.0)$ & I (I.4) & I (I.8) \\
\hline & Wife & $103(81.7)$ & $2(100.0)$ & $23(74.2)$ & $66(83.5)$ & $12(85.7)$ & $54(78.3)$ & $49(86.0)$ \\
\hline & Both & II (8.7) & $0(0.0)$ & $3(9.7)$ & $8(10.1)$ & $0(0.0)$ & $7(10.1)$ & $4(7.0)$ \\
\hline & Neither & $10(7.9)$ & $0(0.0)$ & $3(9.7)$ & $5(6.3)$ & $2(14.3)$ & $7(10.1)$ & $3(5.3)$ \\
\hline \multirow{2}{*}{$\begin{array}{l}\text { Test-tube } \\
\text { babies socially } \\
\text { acceptable? }\end{array}$} & Yes & $93(73.8)$ & $2(100.0)$ & $23(74.2)$ & $59(74.7)$ & $9(64.3)$ & $49(71.0)$ & $44(77.2)$ \\
\hline & No & $33(26.2)$ & $0(0.0)$ & $8(25.8)$ & $20(25.2)$ & $5(35.7)$ & $20(29.0)$ & $13(22.8)$ \\
\hline \multirow{2}{*}{$\begin{array}{l}\text { Fertility } \\
\text { drugs socially } \\
\text { acceptable? }\end{array}$} & Yes & II2 (88.9) & $2(100.0)$ & $28(90.3)$ & 70 (88.6) & $12(85.7)$ & $63(91.3)$ & $49(86.0)$ \\
\hline & No & I4 (II.I) & $0(0.0)$ & $3(9.7)$ & 9 (II.4) & $2(14.3)$ & $6(8.7)$ & $8(14.0)$ \\
\hline
\end{tabular}




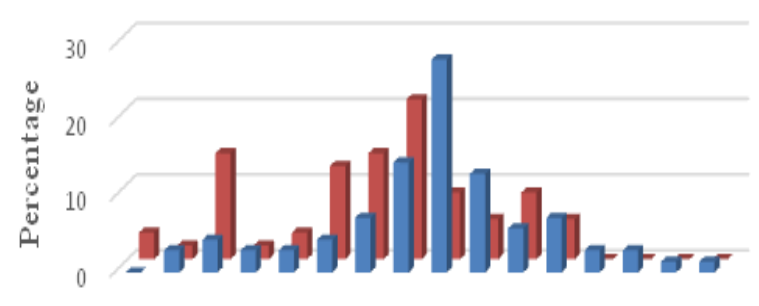

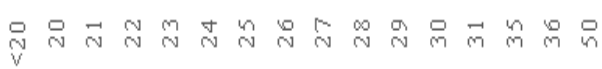

Age (years)

\section{- Male -Female}

Figure I Age distribution of final year medical students in the survey.

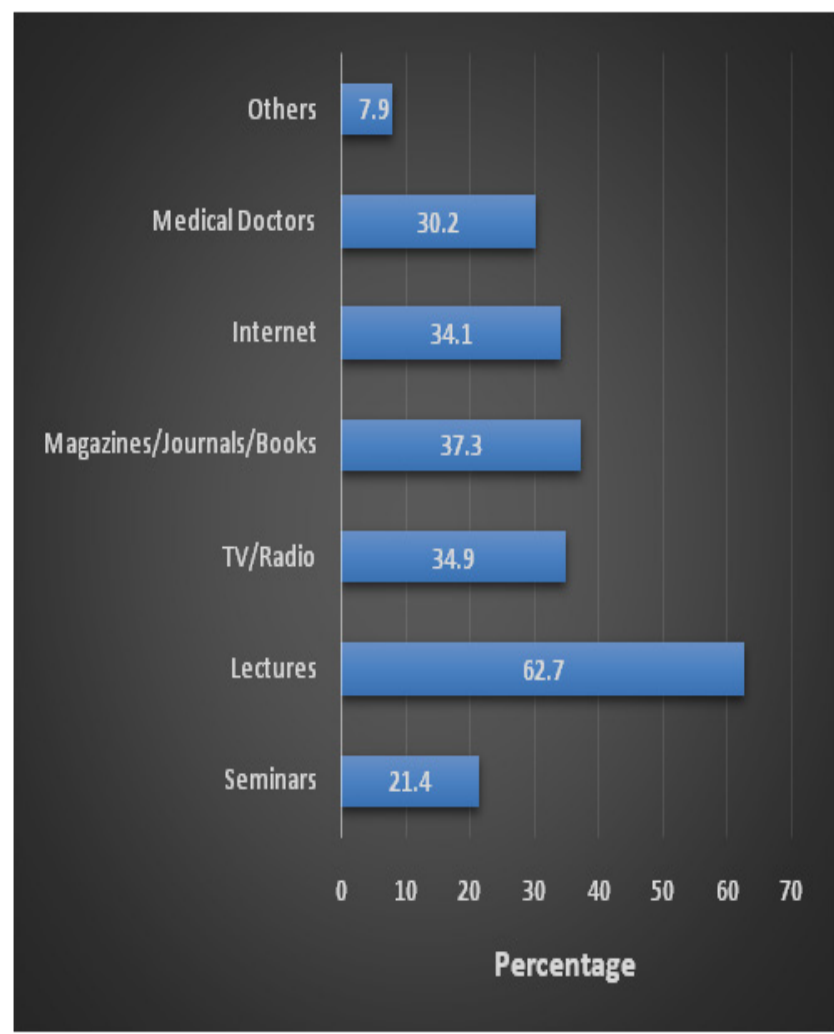

Figure 2 Sources of information on In-vitro fertilization among the medical/ pharmacy students.

\section{How is IVF performed?}

Overall majority of $88.9 \%$ responded by agreeing that bringing egg and sperm together outside the body and putting fertilized egg back into the womb is how IVF is performed. Strangely, $6.3 \%$ said IVF involves growing babies in test tubes for 9 months and one female respondent, aged 25-29 gave a response that IVF involved manufacturing sperm and egg.

\section{Is it possible for a woman to have a baby after meno- pause?}

As expected, the response to this question varied as $7962.7 \%$ ), among whom were $37(69.9 \%)$ females agreed that a woman can have a baby after menopause. Of the $46(36.5 \%)$ who disagreed that a woman can have a baby after menopause, $26(37.7 \%)$ were males and $20(35.1 \%)$ were females.

\section{Are IVF babies normal?}

Most respondents $(106,84.1 \%)$ thought that IVF babies are normal though $9.5 \%$ were unsure whether they are normal or not.

\section{Biggest worry with IVF}

The respondent's biggest worry about IVF was that it is too expensive $(91,72.2 \%)$ and that it does not work all the time. However, $5.6 \%$ of the medical students alluded to the religious perspective of IVF while only $3.2 \%$ are unsure whether IVF babies are normal.

\section{Option in case of infertility?}

It wasn't that strange that about $70 \%$ of the respondents chose IVF as an option in case of being discovered to be unable to naturally have a child.

\section{Who is commonly blamed for infertility in the society?}

Most $(103,81.7 \%)$ respondents were of the view that the woman is often blamed for infertility in the society. Almost equal proportions of the medical students thought that both husband and wife (11, 8.7\%) on one hand and neither $(10,7.9 \%)$ on the other hand, were commonly blamed for infertility.

\section{Test-tube babies socially acceptable?}

Again, majority of the respondents agreed that test-tube babies are socially acceptable, especially females $(44,77.2 \%)$ more than male $(49,71.0 \%)$

\section{Fertility drugs socially acceptable?}

Finally, $112(88.9 \%)$ of the respondents agreed that fertility drugs are or should be socially acceptable, especially among males (63, $91.3 \%)$ and those who were $<20$ years old $(2,100.0 \%)$.

\section{Discussion}

The study was designed to explore the level of knowledge and awareness of IVF among final year medical students attending a College of Medicine in Nigeria. The issue of infertility has not been decisively addressed by any tier of the government or by any public organization in the country. However, annual endometriosis campaign, sponsorship of some television programs on infertility and holding talks and lectures on infertility in tertiary institutions have been undertaken by NFC for the past few years. Infertility probably affects one in every four couples or one in every 15-20 Nigerians, though some of these people eventually become parents of healthy babies. Therefore, infertility may be a transient phenomenon whereby a couple (male and female) may temporarily be unable to have a child but during this time, they may require experts' assistance in having their own child trough procedures such as IVF.

Male respondents were more in proportion and were older than female respondents probably because fewer females opt for medical 
career. The study also observed that final year female medical students were about twice as likely to be married as their male counterparts. Setting up a family is central to a woman's life as early as the opportunity arises. This may be because of the awareness that fecundity wanes as a woman ages. However, only $1(14.3 \%)$ of the 7 married females, in contrast to $3(60.0 \%)$ of the 5 married males, was a parent.

One major finding in this study was that about a third (34.9\%) of the respondents was sexually active in the 6 months prior to the study. This figure is far less than the $75 \%$ obtained from a study among white female final year (senior) students in Michigan, USA. ${ }^{9}$ This low prevalence of sexual activity among the respondents may be due to the rigors of the medical course, especially in the final year of the students. Most of the respondents who were sexually active 6 months prior to the survey had only one heterosexual partner, though all who had 2-3 heterosexual partners were males and those who had $\geq 4$ were females. A survey of adults aged 20-59 indicated that women have an average of 4 sex partners during their lifetime and men have an average of $7,,^{10}$ a record supported by the other study. ${ }^{11}$ Reporting multiple sexual partnership is thus more common among males than among females. ${ }^{12}$ The phenomenon of multiple sexual partners has been linked to high incidence of HIV, ${ }^{12-16}$ other sexually transmitted diseases, ${ }^{9}$ cervicitis ${ }^{17}$ and cervical cancer ${ }^{18}$ in females and prostate cancer in males. ${ }^{19}$

Another finding considered major in this study was that multiple heterosexual partners occurred among all respondents who had their first heterosexual intercourse at age of less than 15years, regardless of whether they were males or females. This finding is at variance with what a study ${ }^{20}$ reported that males $(44.6 \%)$ were expressively more likely than females (35.1\%) to engage in early sexual entrance. Early sexual debut is considered a risk factor for HIV infection, STIs and unwanted pregnancy.

Expectedly, lectures were the main sources of information on IVF among the respondents more than the internet. Sourcing for information on the internet may be limited by inability to own a laptop computer or an internet compliant or internet-ready phone, timeconsuming and attached to cost that student may ill afford, especially if interest is not directed towards infertility or its management.

Information on IVF passed to the students during lectures and from other sources is probably appropriate since majority of them (112, $88.9 \%$ ) had a good understanding of how IVF is performed. Medical experts and specialists in fertility, embryology and gynecology impact step-wise education in the process of solving fertility problems through one form of Assisted Reproductive Technique (ART) or another, starting with ovarian stimulation, using fertility medication to increase the quantity of ovarian follicles and control ovulation time. ${ }^{21}$ This is probably why a large proportion of respondents $(112,88.9 \%)$ agreed that fertility drugs are socially acceptable and why another 89 (70.1\%) opted for IVF in case of infertility.

As noticed in this paper, most respondents claimed that women are more commonly blamed for infertility in the society. This finding agrees with the statement "the infertile woman often blames herself or is blamed by others. ${ }^{22}$ In certain parts of Africa, the common belief is that woman is mainly responsible for infertility, especially after years of marriage, and as such she should be treated as a pariah or an outcast. ${ }^{23}$ However, the rationale for blaming women may not be justified as infertility is soaring among men. ${ }^{24}$

\section{Conclusion}

The study shows an overall good level of knowledge, awareness as well as perception of IVF among medical students. Medical lectures have been a good source of information and IVF as a form of infertility management should be included in the curriculum of medical students. Medical students who should be agents of sociomedical information and change in these parts must be aware of the paradigm shift that women are not more to blame for infertility than their male counterparts. ${ }^{25}$

\section{Study limitations}

This study has some limitations. First it was a convenient sampling of all medical students from a particular geopolitical area of the country and does not necessarily represent the views, opinions and awareness level of medical students from other parts of Nigeria. Also, a control group of non-medical students could probably have strengthened the study. Other groups of students such as those to soon become embryologists, pharmacists, laboratory scientists and IVF Nurses were excluded.

\section{Acknowledgements}

None.

\section{Conflict of interest}

Author declares that there is no conflict of interest.

\section{References}

1. Overview - In vitro fertilization (IVF) - Mayo Clinic.

2. www.mayoclinic.org/tests-procedures/in-vitro-fertilization/home/ovc20206838

3. BBC. The birth of the world's first 'test-tube baby' has been announced in Manchester (England). Louise Brown was born shortly before midnight in Oldham and District General Hospital. 1978.

4. Habbema JDF. Is affordable and cost-effective assisted reproductive technology in low-income countries possible? What should we know to answer the question? Hum Reprod. 2008;2008(1):21-24.

5. https://www.africanlibraryproject.org/our-african-libraries/africa-facts

6. https://www.africanlibraryproject.org/our-african-libraries/africa-facts

7. Virtala A, Vilska S, Huttunen T, et al. Childbearing, the desire to have children, and awareness about the impact of age on female fertility among Finnish university students. Eur $J$ Contracept Reprod Health Care. 2011;16(2):108-115.

8. Obioha JA, Ikechebelu JI, Eleje Gu, et al. Knowledge, and attitude of Nurses towards in-vitro fertiliszation: A prospective cohort study. Gynaecol Cases Rev. 2014;1(1):005.

9. Okwelogu IS, Azuike EC, IKechebelu JI, et al. In-vitro fertilization Practice: Awareness and perceptions among women attending fertility clinics in okija. Anambra state, Nigeria. Afr J Online. 2012;3(2):12.

10. Adesiyun A, Ameh N, Avidime S, et al. Awareness and perception of assisted reproductive technology practice amongst women with infertility in Northern Nigeria. Open Journal of Obstetrics and Gynecology. 2011;1(3):144-148.

11. Joffe GP, Foxman B, Schmidt AJ, et al. Multiple partners and partner choice as risk factors for sexually transmitted disease among female college students. Sex Transm Dis. 1992;19(5):272-278. 
12. Allen CF, Edwards P, Gennari F, et al. Evidence on delay in sexua initiation, multiple partnerships and condom use among young people: review of Caribbean HIV behavioural studies. West Indian Med J. 2013;62(4):292-298

13. Doyle AM, Mavedzenge SN, Plummer ML, et al. The sexual behavior of adolescents in sub-Saharan Africa: patterns and trends from national surveys. Trop Med Int Health. 2012;17(7):796-807.

14. Lurie MN, Rosenthal S. Concurrent partnerships as a driver of the HIV epidemic in sub-Saharan Africa? The evidence is limited. AIDS Behav. 2010;14(1):17-24

15. Mah TL, Halperin DT. Concurrent sexual partnerships and the HIV epidemics in Africa: evidence to move forward. AIDS Behav. 2010;14(1):11-16.

16. Morris M. Barking up the wrong evidence tree. Comment on Lurie \& Rosenthal, Concurrent partnerships as a driver of the HIV epidemic in sub-Saharan Africa? The evidence is limited. AIDS Behav 2010;14(1):31-33.

17. Sawers L, Stillwaggon E. Concurrent sexual partnerships do not explain the HIV epidemics in Africa: a systematic review of the evidence. $J$ Int AIDS Soc. 2010;13:34.

18. http://www.emedicinehealth.com/cervicitis/article_em.htm
19. Liu ZC, Liu WD, Liu YH, et al. Multiple Sexual Partners as a Potential Independent Risk Factor for Cervical Cancer: a Metaanalysis of Epidemiological Studies. Asian Pac J Cancer Prev. 2015;16(9):3893-3900.

20. Kotb AF, Beltagy A, Ismail AM, et al. Sexual activity and the risk of prostate cancer: Review article. Arch Ital Urol Androl. 2005;87(3):214-215

21. Zuma K, Setswe G, Ketye T, et al. Age at Sexual Debut: A Determinant of Multiple Partnership among South African Youth. Afr J Reprod Health. 2010;14(2):46-54

22. Macklon NS, Stouffer RL, Giudice LC, et al. The science behind 25 years of ovarian stimulation for in vitro fertilization. Endocr Rev. 2006;27(2):170.

23. McLeod C, Ponesse J. Infertility and Moral Luck: The Politics of Women Blaming Themselves for Infertility. International Journal of Feminist Approaches to Bioethics. 2008;1(1):126-144.

24. Sackitey S. Are women and sorcery only to blame for infertility in Africa? 2016.

25. Rogers L. Male infertility is soaring. So why do doctors keep blaming the woman when she can't have a baby? FEMAIL investigates. 2012;22:43. 